\title{
IGLESIA MATRIZ DE JAUJA. PLAN DE RECUPERACIÓN Y PROCESO DE INTERVENCIÓN RESTAURATIVA $(2009-2010]^{(*)}$
} JAUJA MATRIX CHURCH. RECOVERY PLAN AND RESTORATIVE INTERVENTION PROCESS [2009-2010]

\author{
HEBNER CUADROS CHÁVEZ ${ }^{(*)]}$ \\ (D) https://orcid.org/0000-0002-8840-125X \\ hebner.cuadros@unmsm.edu.pe \\ Grupo de investigación “Historia y Ciudadanía Activa”, Universidad Nacional Mayor de San Marcos (Perú)
}

Fecha de recepción: 19 de diciembre de 2019

Fecha de aprobación: 14 de junio de 2020

\section{RESUMEN}

Evaluación y diagnóstico de la propuesta de intervención y proceso de recuperación del monumento histórico "Iglesia Matriz" de la ciudad de Jauja, Perú, realizada en los años 2009 y 2010. Análisis exhaustivo del proyecto y de su ejecución, de los criterios metodológicos planteados y utilizados para evaluar su resultado y trascendencia, por tratarse de un bien patrimonial.

Interpretación de la tipología y metodología del proyecto y del proceso de restauración en su contexto político, social y cultural; expectativas, valoración y aceptación de la población sobre el componente cultural que proyecta y da sentido de identidad colectiva e histórica a sus habitantes.

Precisiones y comentarios valorativos al proyecto y a los procedimientos de intervención y de recuperación, haciendo un balance de los criterios, logros, falencias y desventajas respectivas.

\section{PALABRAS CLAVE}

Iglesia Matriz; Jauja Monumental; restauración

\begin{abstract}
Evaluation and diagnosis of the intervention proposal and recovery process of the historical monument "Iglesia Matriz" of the city of Jauja, Peru, carried out in 2009 and 2010. Comprehensive analysis of the project and its execution, of the methodological criteria proposed and used to evaluate its result and significance, as it is a heritage asset.

Interpretation of the typology and methodology of the project and the restoration process in its political, social and cultural context; expectations, assessment and acceptance of the population about the cultural component that projects and gives a sense of collective and historical identity to its inhabitants.

Clarifications and evaluative comments to the project and to the intervention and recovery procedures, taking stock of the respective criteria, achievements, shortcomings and disadvantages.
\end{abstract}

\section{KEYWORDS}

Matrix Church; Monumental Jauja; restoration. 
devenir Vol. 7, N¹4, JULIO - DICIEMBRE 2020, PP. 71-90 - EstudIOS I ISSN 2312-7562 | E-ISSN 2616-4949

UNIVERSIDAD NACIONAL DE INGENIERÍ, LIMA

doi: https://doi.org/10.21754/devenir.v7i14.808

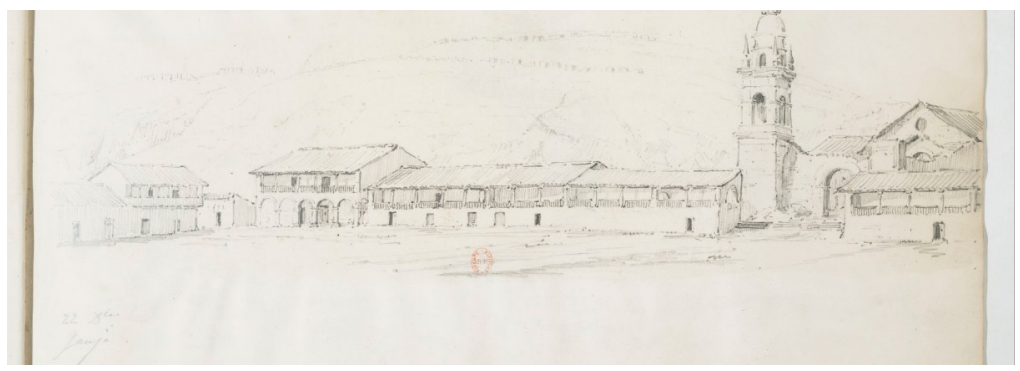

Figura 1. Iglesia Matriz de Jauja y contexto. Dibujo: Leonce Angrand. 1838. Edgardo Rivera Martínez. (Copilador). (1972). Leonce Angrand - Imágenes del Perú en el siglo XIX. Lima, Perú. Ed. Carlos Milla Batres. P. $235 .$.

\section{Introducción}

El presente artículo es una evaluación del proyecto de restauración y un diagnóstico del proceso de intervención y de los criterios metodológicos utilizados para la recuperación de la Iglesia Matriz de Jauja, en el Perú, en base al expediente técnico denominado "Refacción de la Iglesia Matriz de Jauja" que se realizó de manera conjunta y simultánea a otros bienes edificados como parte integrante del proyecto, denominado "Proyecto: Puesta en Valor, Recuperación y Conservación de la Zona Monumental de la Ciudad de Jauja" el año 2010, a cargo del Gobierno Regional de Junín - Perú, mediante la Dirección Regional de turismo y la Gerencia de Obras.

La investigación se desarrolla en dos partes con sus respectivos segmentos:

En la primera parte, concentramos nuestro análisis y apreciación en los fundamentos del proyecto planteado, considerando el momento y el contexto en que se estructuró dicho plan y su objetivo en materia patrimonial y cultural. En el primer segmento se destacan las características y condiciones del bien cultural; en el segundo segmento diagnosticamos la gestión y el proyecto de recuperación y a las entidades que participaron y los presupuestos que acordaron; en tercer lugar, se evalúan las propuestas de intervención del proyecto según las etapas y sectores; y por último se analiza e interpreta el impacto del proyecto en la sociedad local, en función a los valores del bien patrimonial.

En la segunda parte, esbozamos un análisis y apreciación de la metodología, proceso, accionar y resultado de la intervención y ejecución de obra, en la Iglesia Matriz de Jauja. Para ello se contextualizó el trabajo respectivo y se analizaron las consecuencias que tuvo en la colectividad y en el campo del patrimonio cultural.

En primer lugar, desarrollamos los aspectos de significación y el valor de uso del monumento intervenido; en segundo lugar exponemos sobre la restauración del bien y su trascendencia como elemento de identidad y utilidad social; en tercer lugar valoramos los resultados del proceso de intervención de acuerdo con la técnica, forma y estética; en cuarto lugar planteamos un comentario crítico sobre las acciones de intervención, destacando las conclusiones respectivas y anexando las imágenes que sustentan lo referido.

La finalidad de este artículo es contribuir en el análisis de los procesos de restauración del patrimonio arquitectónico, que se desarrollan en nuestro país. Para ello, compartimos las interpretaciones del diagnóstico y evaluación en la ejecución de la obra en cuanto a la recuperación del monumento religioso en la ciudad de Jauja.

Por ahora compartimos esta reseña que evalúa la restauración de la Iglesia Matriz de Jauja, aporte que esperamos sea acogido por la comunidad académica y por la sociedad en general. Finalmente, nos comprometemos a seguir hurgando en tópicos vinculados con el patrimonio cultural, para compartir nuestros análisis y juicios de valor, por ser parte del derecho a la cultura y la democratización cultural (ver Figura 1). 


\section{Iglesia Matriz de Jauja. Plan de recuperación y proceso de intervención restaurativa}

La Iglesia Matriz se encuentra situada en la cabecera de la Plaza Mayor de la ciudad de Jauja, provincia del mismo nombre, departamento de Junín, Perú; edilicio que obtuvo el reconocimiento y la declaratoria patrimonial, con Resolución Jefatural № 515-89-IN$\mathrm{C} / \mathrm{J}$, de fecha 11/08/89, en la categoría de Monumento Religioso, por sus condiciones históricas, arquitectónicas y artísticas.

Fue erigida desde 1563 por la Orden Religiosa Franciscana, junto con el Convento Santa Fe de Jauja, Cabecera de Doctrina de la orden religiosa en su calidad de Guardianía.

Tuvo diversas intervenciones parciales a partir del siglo XIX, hasta cambiar su configuración original en un $60 \%$ con las acciones restaurativas desde principios del siglo XX hasta inicios del siglo XXI, sustituyéndose los elementos arquitectónicos y enlucidos en los paramentos de muros de la fachada y del lateral izquierdo, en la cubierta y en los interiores (murales, capillas, retablos y piso), donde se retiraron antiguos componentes y se incorporaron otros, de acuerdo con las corrientes estilísticas imperantes.

Edificación de origen colonial y condición mestiza, de vital significación en la colectividad local y regional, reflejadas en las acciones ${ }^{1}$ de conservación y restauración por el valor de uso social del recinto en más de cuatro siglos de existencia.

Su estructura perduró como testimonio arquitectónico con características propias de las iglesias rurales andinas, construidas durante el periodo colonial peruano, alcanzando una configuración estilística de neo barroco. ${ }^{2}$

La representatividad histórica de la iglesia es emblemática en la Región de Junín, con especial énfasis en la jurisdicción provincial del monumento y de su vinculación, mediante la conexión religiosa, con el pasado como identidad.

(...) el ansia de pasado es una de las manifestaciones más significativas(...) ante la conciencia de perdida de continuidad cultural(...) el pasado sigue teniendo hoy la fuerza potente que siempre tuvo en los asuntos humanos, como fuente de identidad personal y colectiva y como baluarte contra el cambio masivo y angustiante. (Ballart, 2002, p. 37)

Esta motivación social se reflejó en el cuidado y permanencia del monumento religioso, como forma de contrarrestar la transformación de su imaginario cultural por efectos de la modernidad, ya que dicho patrimonio cobró significado, con mayor fuerza cuando fue visibilizado mediáticamente a razón de su proceso de recuperación y de restauración.

(...) ¿Qué es lo que realmente vale, la reliquia, el resto del pasado en sí... o el pasado que incorpora y le da sentido, esa abstracción que tira de nosotros?(...) ¿Qué papel juega esa abstracción llamada pasado en la vida de los seres humanos? y ¿Qué cosas buenas espera obtener la sociedad y cada una de las personas del pasado? (Ballart, 2002, p. 38)

Entonces, esta edilicia, generó memoria y sentido histórico en la comunidad, porque el ciudadano siente reconocimiento, pertenencia, identidad, conocimiento y continuidad de su historia y cultura. "Con el patrimonio el pasado se personifica... porque pertenece al mundo de lo sensible" (Ballart, 2002, p. 42).

\footnotetext{
1. Los proyectos y las gestiones de intervenciones fueron propiciadas por las Cofradías.

2. Especialmente por los elementos decorativos de la fachada, la incorporación de columnas pareadas y nervaduras en la bóveda de la nave de la iglesia, de forma imitativa, sin tratamiento académico. Sin embargo, aún perduran otros elementos propios del barroco clásico, como las capillas y los altares retablos.
} 


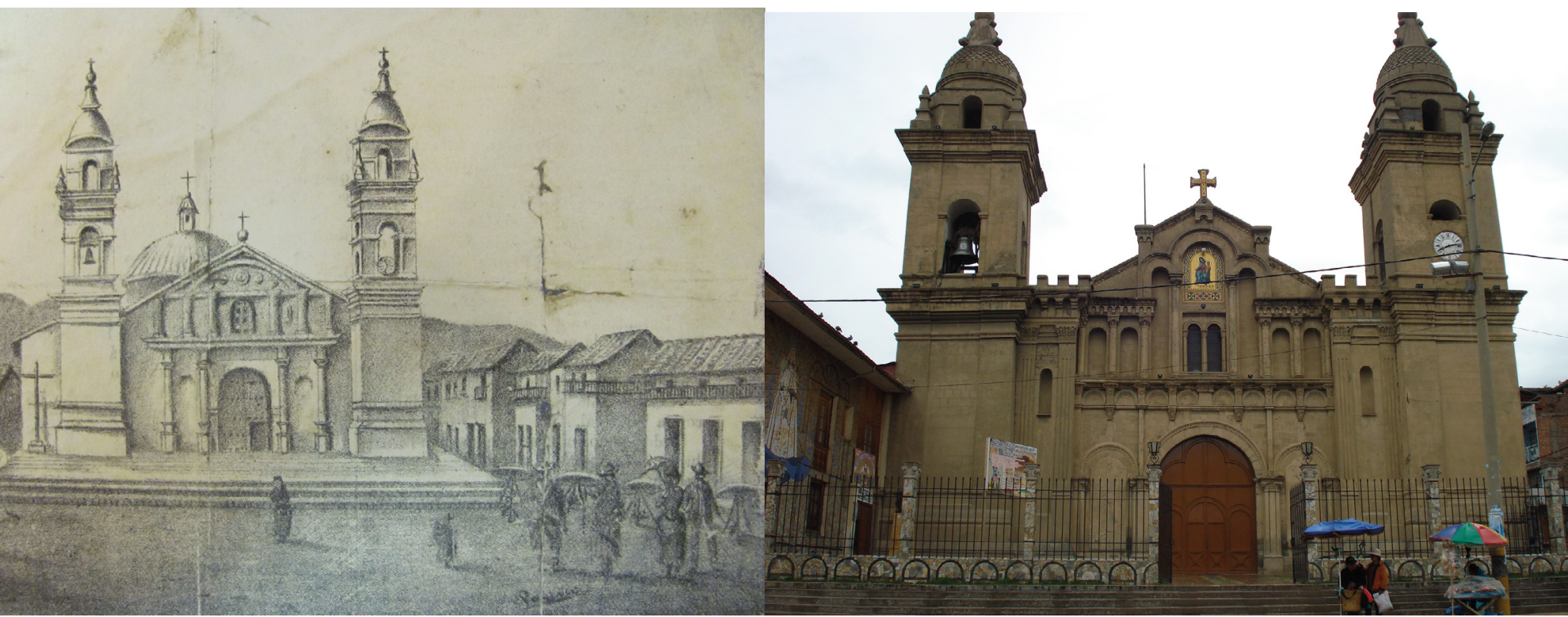

Figura 2. Iglesia Matriz de Jauja y contexto. Dibujo (detalle), P. Ruíz. Fines del siglo XIX. Lámina adherida a la contratapa, encuadernado del semanario "El Pueblo", Volumen 2, Huancayo $1912-1913$.

Figura 3. Iglesia Matriz de Jauja antes de su intervención. Archivo fotográfico del autor, 2009.
Es una edificación (...) construida bajo el prototipo del estilo renacentista... con las características arquitectónicas de las iglesias rurales (...) También se adecua [i.e. adecuó] tardíamente a los cambios estilísticos europeos, incorporando el estilo barroco y neoclásico, sobre todo en la retablística.

Las pinturas de formidable factura que tuvo la Iglesia Matriz de Jauja, se han perdido en su gran mayoría (...) tanto lienzos como pinturas murales(...) (Cuadros, 2012, p. 11) (ver Figuras 2 y 3 )

\section{Diagnóstico de la gestión y proyecto de recuperación}

El proceso de planificación, las acciones de la propuesta de conservación y restauración de la Iglesia Matriz de Jauja en el año 2010, formó parte de un proyecto macro denominado Proyecto: Puesta en valor, recuperación y conservación de la zona monumental de la ciudad de Jauja, impulsado por la autoridad de turno del Gobierno Regional de Junín. La iglesia fue un componente importante para el proceso de restauración, tanto por el interés de la institución ejecutora como por la expectativa de los actores sociales-locales beneficiados y la sociedad regional, por el simbolismo religioso, cultural y de identidad que generaba. "... testimonial de un sinnúmero de episodios históricos desde los primeros días de la colonia; considerada una joya arquitectónica... lo que causa admiración de los visitantes..." (García, 2011, p. 2).

Contextualmente, el proyecto se desarrolla en un ámbito político, económico, social y cultural favorable, en una coyuntura de relativa bonanza financiera para actividades de "desarrollo" regional, como forma de inclusión social y progreso "sostenible"; además, se da en una etapa cercana a las reelecciones de gobiernos regionales, donde la gestión, cumplimiento y conformidad de proyectos, es garantía de continuidad política y de gobernabilidad.

El Gobierno Regional de Junín, presidido el año 2010 por el Sr. Vladimiro Huaroc Portocarrero, no tuvo cercanía con el Gobierno central para lograr el apoyo pleno, pero si gozaba del respaldo popular masivo, por avizorar y certificar planes de desarrollo alternativo, vitales para la colectiva, especialmente en materia cultural. Según García se destinaron "S/ 664,784.28 para nuestra bella Iglesia Matriz". (2011, p. 2).

Figura 3. Iglesia Matriz de Jauja antes de su intervención. Archivo fotográfico del autor, 2009. 


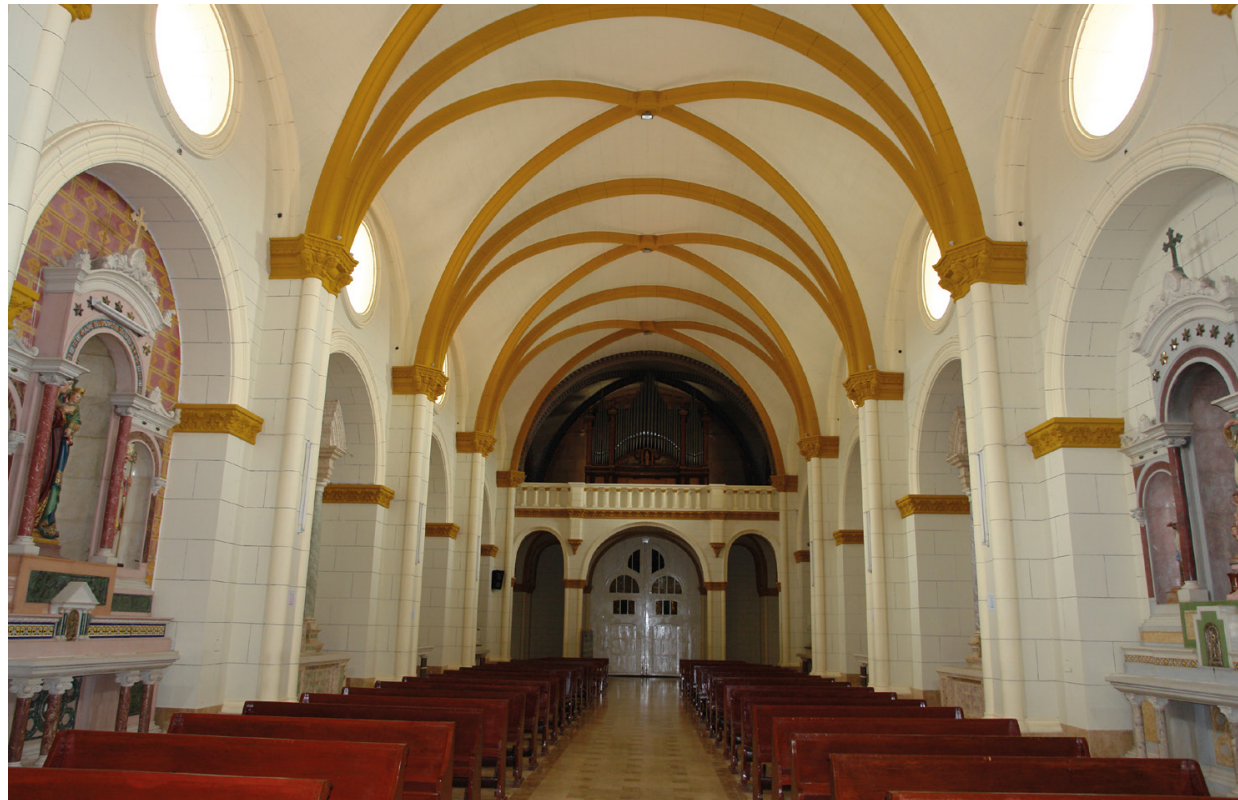

El monto, 10\% del presupuesto total, fue destinado a la edilicia; pero sí tomamos en cuenta que dicho proyecto era parte de un conjunto de proyectos de restauración denominados simbólicamente Jauja Monumental, donde había más de 20 inmuebles para ser recuperados y dos calles para ser peatonalizadas, el proyecto de restauración de la iglesia recibió la mayor cantidad de inversión (si consideramos la cantidad de otros componentes dentro del plan macro) porque el expediente técnico arrojó esta necesidad presupuestal para su intervención, aunque esa suma no era lo idóneo y favorable en ese momento, en vista de que había otros componentes patrimoniales de la iglesia que requerían ser restaurados.

En lo social, la provincia de Jauja se caracterizó por su cohesión, unidad y dinamismo en planes de desarrollo local, por eso recibió la propuesta del proyecto para la intervención de la Iglesia Matriz con beneplácito, porque acentuaba su condición de ser la ciudad de la sierra central con la mayor cantidad y calidad de bienes inmuebles de valor histórico y estético declarados patrimonio, por lo tanto, se afianzaba su identidad cultural colectiva. Dicha identidad se fortaleció por el compromiso de la sociedad civil activa de la ciudad de Jauja, como su clase dirigente e intelectual, tanto los residentes locales como los residentes jaujinos en la capital peruana y el extranjero, que de manera directa e indirecta influyeron para lograr una decisión política trascendental como gestión cultural de envergadura en la zona monumental de Jauja.

El 01 de julio se dio inicio simbólico a las obras del Proyecto "Puesta en valor, recuperación y conservación de la Zona Monumental de la ciudad de Jauja, Primera Capital del Perú"... el trabajo fue entregada [sic] a la población en la fecha. (García, 2011, p. 2)

Y según Huaroc: "... se tomó la decisión de llevar a cabo un proyecto que permita revalorar lo que la ciudad ha sido, a fin de generar un desarrollo económico sostenible a partir de su múltiple patrimonio..." (2010, p. 7).

La ciudad de Jauja atravesaba una transformación cultural, producto de la globalización del mercado, que subrepticiamente influenciaba en la estética urbana y en sus valoraciones patrimoniales. A pesar de la tradición intelectual y artística que caracterizaba a la localidad, surgieron rápidamente sectores discordantes de conservacionistas y modernistas. Los primeros, románticamente añoraban la apacibilidad de su otrora
Figura 4. Detalle de la nave de Iglesia Matriz de Jauja antes de su intervención. Archivo fotográfico del autor, 2009. 


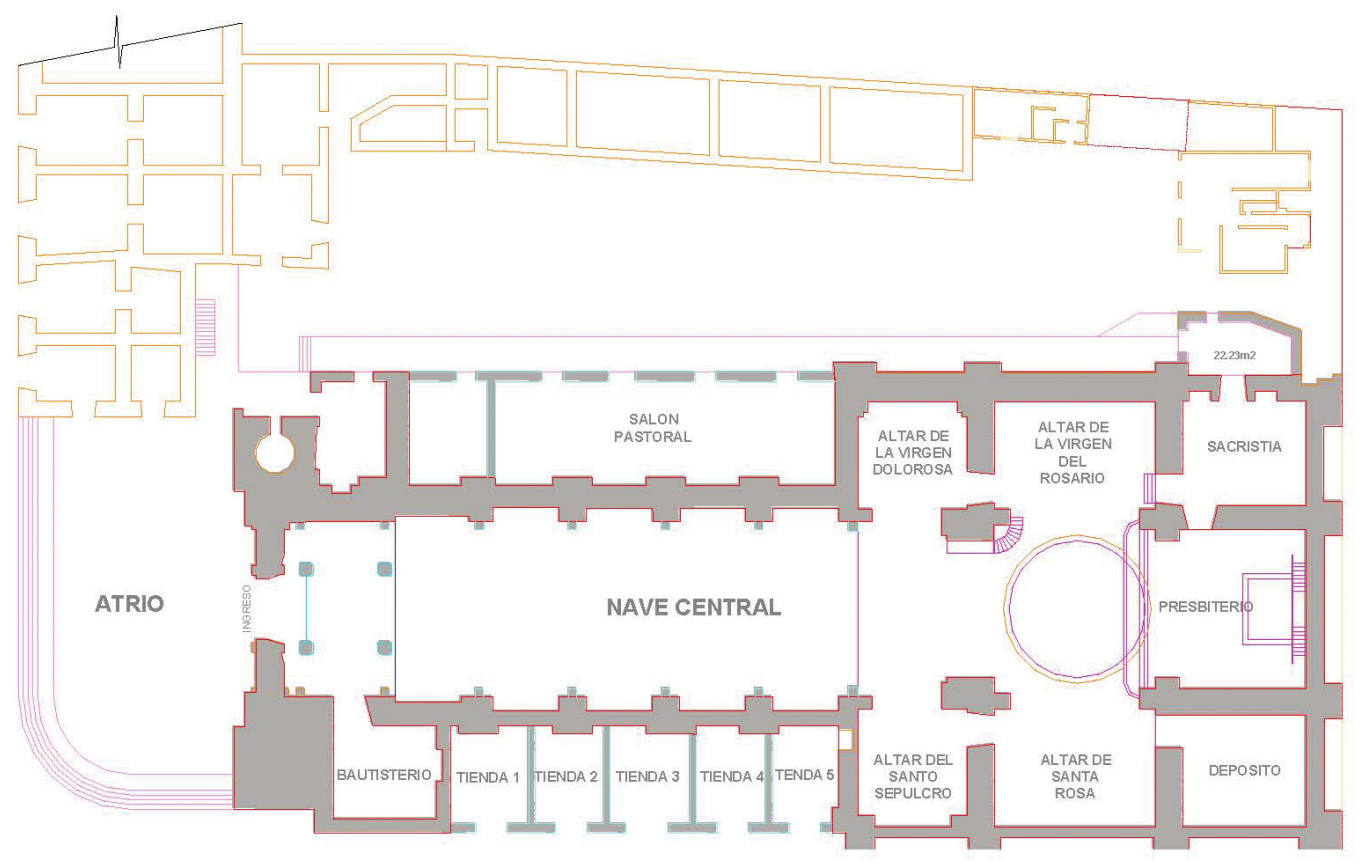

\section{PLANO DE DISTRIBUCIÓN}

Figura 5. Planta de la Iglesia Matriz de Jauja, elaborada para estructurar el expediente técnico Archivo de Armando Chipana. 2009.

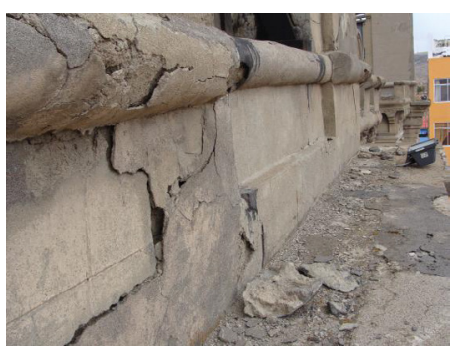

Figura 6. Detalle del alfeizar de la torre campanario de la Iglesia Matriz de Jauja, en el proceso de diagnóstico para elaborar el expediente técnico. Archivo fotográfico de Armando Chipána, 2009. urbe y cuestionaban la "continua devastación de sus históricos bienes arquitectónicos" como forma de "desarrollo urbano", los otros, fundamentaban la urgencia de una "modernidad urbana" como símbolo de progreso social, justificando y promoviendo intervenciones de esa naturaleza, donde irresponsablemente comprometieron a la iglesia matriz con acciones incorrectas como el levantamiento de las baldosas antiguas del piso, la destrucción de su patrimonio mueble como el Órgano musical de estilo renacentista del siglo XIX, la intervención inconsulta y sin autorización del histórico altar retablo lateral "Virgen del Rosario", entre otras labores inaceptables; que luego, por disposición de la autoridad pertinente del entonces Instituto Nacional de Cultura se paralizaron dichos trabajos, hasta su posterior incorporación en la etapa de ejecución del proyecto Jauja Monumental, para un adecuado restablecimiento "... Jauja ejerce una fascinación... tiene una personalidad... a 'la Primera Capital del Perú' la define un espíritu intelectual, analítico y artístico... antes y ahora." (Huaroc, 2010, p. 7).

\section{Proceso de evaluación y estudios sobre la condición del bien edificado}

La evaluación y estudios para la preparación del expediente técnico lo realizó el arquitecto Armando Chipana León, considerando la estructura constructiva, los componentes y elementos decorativos, evaluando las condiciones de uso para establecer propuestas de intervención (ver Figuras 4, 5 y 6).

En los diagnósticos destacan los materiales constructivos utilizados, la forma de edificación, los acabados, los cimientos, pisos, muros, revestimientos y cubierta; así mismo, las condiciones de los componentes de carpintería, de los enlucidos decorativos, de las pinturas murales y de los bienes culturales muebles; los estudios de la fachada, de las torres, del campanario, de la nave principal y de la cúpula, en cuanto a su carácter arquitectónico (ver Tablas 1 y 2). Con esos datos, establecieron que la iglesia en su conjunto presentaba un estado de conservación regular, y bajo estos indicadores procedieron a delinear las respectivas propuestas técnicas para su intervención.

En la elaboración del expediente técnico, se enfatizó en la limpieza de los muros, retiro del cemento, reintegración, consolidación, restauración y mantenimiento de elementos arquitectónico; la elaboración de la data histórica de la iglesia, el levantamiento de planos, cortes longitudinales y alzado. Se realizó el registro fotográfico minucio- 
Tabla 1: Matriz de considerandos del proyecto (A)

\section{Matriz de considerandos (A)}

\begin{tabular}{|c|c|c|}
\hline $\mathbf{N}^{\circ}$ & Componentes & Diagnóstico al proyecto \\
\hline 1 & Cimientos & $\begin{array}{l}\text { A falta de calas estratigráficas no pudieron precisar las } \\
\text { condiciones específicas, se basaron en la observación y } \\
\text { concluyeron que se encontraban en un estado de conser- } \\
\text { vación adecuado. }\end{array}$ \\
\hline 2 & Muros & $\begin{array}{l}\text { Determinaron la utilización del adobe como material cons- } \\
\text { tructivo mayoritario, que a la fecha de evaluación presen- } \\
\text { taban revestimientos de cemento casi en la totalidad de } \\
\text { los espacios externos e internos de la iglesia, confirmaron } \\
\text { también, la presencia de humedad y deterioro en } \\
\text { ciertos sectores. }\end{array}$ \\
\hline 3 & Pisos & $\begin{array}{l}\text { En sectores del atrio encontraron evidencias de piedra de } \\
\text { canto rodado (originalmente el piso fue de ladrillo paste- } \\
\text { lero) y en cuanto a la nave, predominaba el mármol y en } \\
\text { algunos compartimientos el amachimbrado con madera } \\
\text { de pino. }\end{array}$ \\
\hline
\end{tabular}

$4 \quad$ Cubierta

$5 \quad$ Enlucido interior

$6 \quad$ Cielo raso

$7 \quad$ Carpinteria Siglo XIX
Señalaron que tenía la estructura de madera de par y nudillo sobre el cual descansaban las tejas, también encontraron sectores en el crucero con presencia de calamina que mostraban filtraciones y deterioros.

Explicaron la presencia de revestimiento de cemento, especialmente en la nave, en el sotacoro y en el crucero, así como la aplicación de yeso en el resto de los ambientes.
... En las visitas realizadas, no se ha podido identificar el tipo de cimentación por no tener la facilidad de realizar una cala junto a... los muros. De la observación en campo (muros), en la mayoría de los ambientes no presenta problemas de asentamientos (fisuras verticales), por lo que se encuentra en buen estado de conservación. (Chipana, 2009, p. 8)

... muros de adobes, el exterior e interior revestido con concreto... no presentan mayores problemas de humedad... La superficie exterior muestra desprendimientos de pintura, por lo que se encuentran en regular estado de conservación. El muro testero esta revestido totalmente en concreto, presenta deterioro en la pintura y mosaico ubicado en la parte superior de la fachada posterior. (Chipana, 2009, p. 8)

... El piso del atrio es de canto rodado... el de la nave está compuesto de losas de mármol... en el ambiente del depósito conserva el piso original de ladrillo pastelero, las tiendas, ambientes del lado izquierdo es de madera pino oregón; de la sacristía y despensero es de baldosas de concreto decorada, se encuentran en regular estado de conservación. (Chipana, 2009, p. 8)

... sistema de par y nudillo, con cubierta de tejas de arcilla cocida, el ala derecha del segundo crucero y de la cúpula es de cubierta de chapa ondulada (calamina)... En la cúpula se puede observar filtraciones pluviales debido a... desgaste de la chapa, por lo que se encuentra en mal estado de conservación. (Chipana, 2009, p. 9)

... Los revestimientos del interior del sotacoro, nave, cruceros y presbiterio son de concreto con bruñas en buen estado de conservación; el resto de los ambientes son de yeso en regular estado de conservación... En el exterior son de concreto en regular estado de conservación presenta algunos desprendimientos y lavados de la pintura. (Chipana, 2009, p. 10)

... Sacristía y Bautisterio, son de láminas de metal con ornamentos de principios del siglo XX, el de la sacristía presenta deterioro debido a las filtraciones pluviales antiguas. Del coro, nave y cruceros es la bóveda de concreto; presenta pintura mural en el coro. (Chipana, 2009, p. 10)

Chipana, Armando. (2009). Proyecto: "Puesta en Valor, Recuperación y Conservación de laZona Monumental de la Ciudad de Jauja”. Componente: Refacción Iglesia Matriz de Jauja. Huancayo, Perú: Informe técnico.

so del bien a intervenir, fundamentando la propuesta técnica con sustento de los requerimientos logísticos y presupuestales. Por consiguiente, la propuesta técnica de restauración se centró en la conservación preventiva del contexto y la superficie del inmueble, con el retiro de elementos ajenos a su estructura (ver Tabla 3).

Las propuestas técnicas para la intervención del bien inmueble, respondieron al contexto en el manejo de la inversión pública, porque que en ese momento el Gobierno 
devenir Vol. 7, N¹4, JULIO - DICIEMBRE 2020, PP. 71-90 - EstudIOS I ISSN 2312-7562 | E-ISSN 2616-4949

UNIVERSIDAD NACIONAL DE INGGENIERÍA, LIMA

doi: https://doi.org/10.21754/devenir.v7i14.808

Tabla 2: Matriz de considerandos del proyecto (B)

Matriz de considerandos (B)

\begin{tabular}{lll}
\hline $\mathbf{N}^{\circ}$ & Componentes & \multicolumn{1}{c}{ Diagnóstico al proyecto } \\
\hline $8 \quad$ Torres & $\begin{array}{l}\text { Verificaron el material constructivo de piedra calcárea, } \\
\text { unidas con mortero de cal y revestidas con cemento a } \\
\text { principios del siglo XX, y a la fecha de evaluación presen- } \\
\text { taban daños en la superficie y la torre izquierda llevaba } \\
\text { refuerzos de fierro. }\end{array}$ \\
& \\
& Fachada & $\begin{array}{l}\text { Advierten el material constructivo de adobe, el recubri- } \\
\text { miento de piedras desbastadas, la incorporación de } \\
\text { elementos decorativos (esculturas en relieve de 1914 del } \\
\text { artista peruano Wenseslao Hinostroza) y el enlucido total } \\
\text { de cemento, refiriendo su mal estado de conservación por } \\
\text { desprendimiento en sectores específicos. Finalmente se } \\
\text { menciona la existencia de un valioso mosaico. }\end{array}$
\end{tabular}

10 Nave puntualizó la transformación a principios del siglo $\mathrm{XX}$, tanto en sus muros y bóveda, con la incorporación de columnas y mencionan los daños de filtración y humedad en ciertos sectores de estos elementos.

.. construidas con piedra calcárea asentadas con mortero de cal y arena, revestidas con concreto en los primeros años del siglo XX (1921), el cual por efectos propios del comportamiento natural de las piedras el concreto ha sido expulsado, dañando la superficie de la piedra y elementos decorativos como las cornisas. A efectos del sismo de 1947 , la torre izquierda fue reforzada con varillas de fierro corrugado. (Chipana, 2009, p. 10)

... Construida con adobes y enchapadas con piedras canteadas, al que se han adicionado elementos decorativos de concreto como columnas, arcos de medio punto, frisos, pilastras estriadas, capiteles corintios... transformándose el diseño original... también presenta problemas de adherencia del concreto en la superficie... En la fachada existe mosaicos de mucho valor artístico, en buen estado de conservación. (Chipana, 2009, p. 12)

... En los años de 1914 al $1921 \ldots$ el interior de la nave ... es transformada al haber sido implantada columnas de concreto armado y nervaduras en la superficie de la bóveda... se encuentra en buen estado de conservación, con excepción en el encuentro con la torre izquierda donde se presenta filtraciones pluviales por consiguiente humedad y salinización. (Chipana, 2009, p. 14)

11 Cúpula (interior) Determinaron el mal estado de conservación de las pinturas murales, por presentar fisuras, craquelaciónes y humedad, a causa de filtraciones de agua. "... Presenta pintura mural de buena calidad... culminadas en 1935, se están dañando por las filtraciones de agua... requiere su recuperación y conservación..." (Chipana, 2009, p. 15).

12 Bienes muebles Se destacó los altares retablos antiguos de estilo barroco ensamblados en madera, y los altares retablos modernos de estilo neoclásicos construidos con estuco y mármol, considerándolos de regular y buen estado de conservación respectivamente.

... La iglesia cuenta con un retablo mayor y cuatro retablos laterales ubicados en los cruceros de la nave, tallados en madera, dorados en pan de oro del siglo XVIII, en regular estado de conservación, mostrando desprendimientos del dorado y elementos artísticos sueltos. Las imágenes también se encuentran en regular estado de conservación algunos fueron repintados inadecuadamente que han dañado la obra de arte. Los retablos ubicados en la nave, son de concreto revestidos con marmolina, en buen estado de conservación, así como las imágenes, todos ellos pertenecen a los primeros años del siglo $\mathrm{XX}$, de buena factura artística. (Chipana, 2009, p. 12)

Chipana, Armando. (2009). Proyecto: "Puesta en Valor, Recuperación y Conservación de la Zona Monumental de la Ciudad de Jauja". Componente: Refacción Iglesia Matriz de Jauja. Huancayo, Perú: Informe técnico.

Regional de Junín propiciaba costear proyectos en el campo patrimonial; y en tal sentido las propuestas técnicas fueron favorables, en cuanto permitieron las gestiones presupuestales (ya que la intención fue conseguir el financiamiento para su ejecución), sin embargo, el hecho de garantizar una partida económica, estimuló a la elaboración apresurada del expediente técnico, sin términos de referencia exigentes y sin la revisión exhaustiva por parte de la entidad supervisora de bienes patrimoniales. Pero a pesar de esos inconvenientes, en el perfil técnico solo fue redimible el diagnóstico sobre la condición y estado de conservación de la iglesia (ver Figuras 7 y 8 ).

En consecuencia, las propuestas de intervención planteaban acciones simples y un procedimiento de restauración ajeno a las normas técnicas, que pondría en riesgo a la edifi- 
Tabla 3: Matriz de propuestas técnicas de intervención restaurativa.

\begin{tabular}{|c|c|c|}
\hline \multicolumn{3}{|r|}{ Matriz de propuestas técnicas de intervención restaurativa } \\
\hline $\mathbf{N}^{\circ}$ & Componentes & Propuestas \\
\hline 1 & Cubierta & $\begin{array}{l}\text { Se propuso la restitución de tejas dañadas y la integración de mortero de barro en lugares faltantes, tam- } \\
\text { bién se recomendó las calaminas en algunos sectores y el sellado con pintura anticorrosiva de las partes } \\
\text { ligeramente dañadas, para evitar filtración. Finalmente se planteó el reforzamiento de su estructura. }\end{array}$ \\
\hline 2 & Fachada & $\begin{array}{l}\text { Se consideró el retiro total del enlucido de cemento, el reforzamiento de las torres con mortero de cal y } \\
\text { mezcla de cemento, enluciéndose luego con pintura de cal. }\end{array}$ \\
\hline 3 & Parte central & $\begin{array}{l}\text { Se determinó conservar los elementos decorativos del volumen, por corresponder al estilo del templo, } \\
\text { desde su última intervención a principios del siglo XX. }\end{array}$ \\
\hline 4 & Problemas de las sales & Se recomendó un análisis químico del cemento y la desalineación de las piedras en la base de los muros. \\
\hline 5 & $\begin{array}{l}\text { Aplicaciones decorativas de } \\
\text { cemento }\end{array}$ & $\begin{array}{l}\text { Se exhortó cambiarlas, con material de fibra de vidrio ya que estás fueron perjudiciales al muro de } \\
\text { adobe, enfatizando en la conservación del frontis. }\end{array}$ \\
\hline 6 & Cúpula & Se proyectó su conservación exterior y la restauración de la pintura mural en su interior. \\
\hline 7 & Altares retablos y pintura mural & $\begin{array}{l}\text { Se programó la restauración del altar retablo mayor y de los altares retablos laterales, la restauración } \\
\text { de la pintura mural antigua, junto con las esculturas por ser parte integrante de la ornamentación del } \\
\text { interior de la iglesia. }\end{array}$ \\
\hline 8 & Elementos decorativos & $\begin{array}{l}\text { La conservación de las cornisas y ornamentación pictórica del artesonado metálico en la sacristía de la } \\
\text { iglesia de principios del siglo XX, por tener buena factura estética. }\end{array}$ \\
\hline
\end{tabular}

cación -como lo fue- al ser intervenida superficialmente, a modo de maquillaje. A pesar de ello, la propuesta logró receptividad en la colectividad, porque las consideraciones en el proyecto de intervención estaban orientadas a las exigencias y a los intereses de la población, más allá de cumplimientos estrictamente técnicos en cuanto a componentes patrimoniales, es decir, la aceptación ciudadana era fundamental desde el momento de la gestación del proyecto, primero por tratarse de un bien con valor de uso estrictamente simbólico, segundo por ser un bien edificado en un contexto de tradición histórica regional y nacional, tercero por lo que representaba en términos de identidad, impulsando la formación de un patronato para velar por la aceptación del proyecto, la ejecución y el cumplimiento del mismo. "Con ocasión de la colocación de la primera piedra -julio 2010 - se nombró y juramentó el Patronato encargado de la supervisión de las obras... para el trabajo de fiscalización que es de su competencia." (García, 2011, p. 2).

\section{Diagnóstico del proceso de intervención}

Las condiciones, técnicas y métodos de restauración de la Iglesia Matriz de Jauja, se da en un periodo donde las condiciones teóricas y científicas para esos fines eran explícitas y las normas patrimoniales estrictas para una apropiada conservación. La supervisión general estaba a cargo del arquitecto Cesar Martínez, y como residente de obra el arquitecto Percy Vílchez, con quien se culminó el proyecto, y que en opinión del experto arquitecto restaurador José María Gálvez los criterios de restauración fueron regulares "Integrada, fachadista". (J. Gálvez, comunicación personal, 06 de diciembre de 2018).

La restauración de la Iglesia Matriz de Jauja el año 2010, se dio en un escenario de múltiples intervenciones que el Gobierno Regional de Junín puso en marcha y se inició con el mejoramiento del entorno de la plaza mayor y las principales calles del centro histórico denominados Jauja Monumental de la que también formaba parte el monumento religioso.

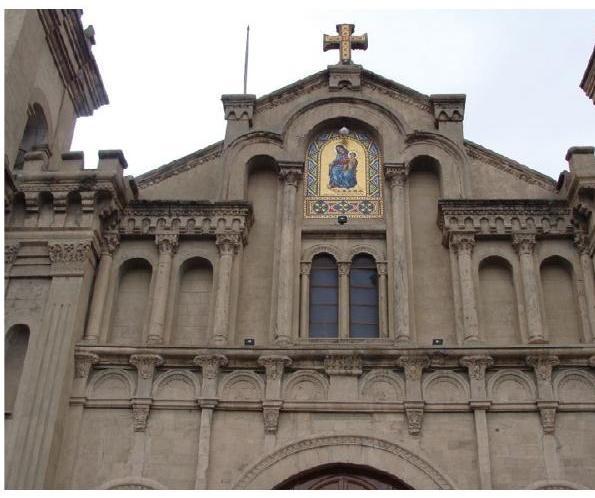

Figura 7. Iglesia Matriz de Jauja, en el proceso de diagnóstico para elaborar el expediente técnico. Archivo fotográfico de Armando Chipána, 2009. 


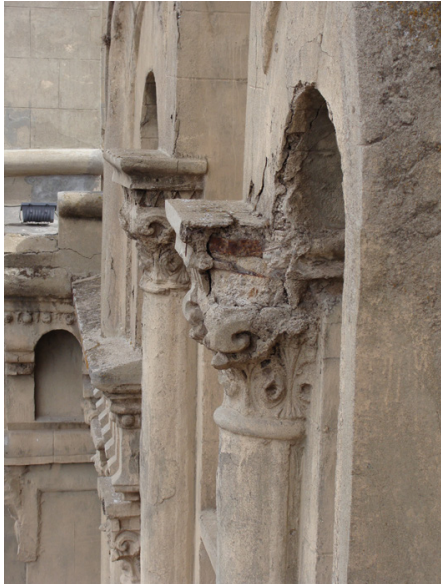

Figura 8. Detalle de capitel de la Iglesia Matriz de Jauja, en el proceso de diagnóstico para elaborar el expediente técnico Archivo fotográfico de Armando Chipána, 2009.
Ese año se daba inicio con la gestión de la nueva cartera del Ministerio de Cultura, la que remplazaba al antiguo Instituto Nacional de Cultura; vinculantes en la gestión cultural. La sociedad local, también impulsó la conservación y restauración de componentes culturales patrimoniales muebles e inmuebles, pertenecientes a las iglesias del sector, a través de sus cofradías y asociaciones religiosas, como el caso de la restauración parcial del Altar Retablo Mayor de la Iglesia Matriz de la ciudad de Jauja, a estas motivaciones se sumaban proyectos para la restauración de retablos laterales de la misma edilicia de Jauja, que para ese momento se encontraba en evaluación del Ministerio de Cultura. Todo ello, generaba un imaginario de compromiso cultural.

Políticamente, había una voluntad de apoyo a este tipo de gestión, porque el gobierno regional y el municipio provincial entendían y avizoraban como un potencial recurso turístico, ya que se trataba de un centro histórico de la ciudad más antigua de la región central. Así mismo, las autoridades concertaban compromisos de apoyo económico, para impulsar programas turísticos de difusión e implementación.

En esa agitación cultural, también se desataba los hurtos de bienes culturales muebles religiosos, especialmente en las iglesias antiguas de la Provincia de Jauja y en la misma Iglesia Matriz de la ciudad que estaba siendo intervenida, por lo que, la Dirección Desconcentrada de Cultura de Junín reiniciaba una campaña de emergencia para el inventario y catalogación de los bienes muebles.

El estado de conservación de la iglesia, al momento de su intervención, era bueno, por encima del estándar "regular" en la estructura, en los enlucidos de fachada e interior de la nave. Para entonces, lucía un piso con baldosas nuevas, una carpintería lustrosa que contrariaba la buena práctica de la conservación preventiva, mantenía el antiguo revoque de cemento en la fachada y los del interior; destacaba los altares retablos de estilo neoclásico con enchapes de mármol, construidos en el siglo XX, y se exhibía el altar retablo mayor en su primera etapa de restauración. Se sumaban, los altares retablos laterales de estilo barroco ${ }^{3}$, abandonados por el tiempo y disturbados por inadecuadas intervenciones, las pinturas murales presentaban agrietamientos en su superficie y ciertos sectores de los muros mostraban humedad, a consecuencia de filtraciones.

Bajo estas condiciones, la arquitectura de la Iglesia, fue intervenida en cuatro sectores: en el paramento de la fachada, en la cubierta, en las torres y en el altar retablo mayor'. Las acciones fueron desarrolladas de acuerdo al expediente técnico, con medios y recursos según el plan, ejecutado de forma paralela y con etapas programadas, siendo la fachada el sector principal. La intervención se realizó con dos equipos de trabajo, para el componente arquitectónico y para los retablos de la segunda etapa, el primer equipo asumió el sector de la fachada, torres y cubierta.

Los trabajos se desarrollaron con métodos tradicionales, de restablecimiento histórico y estético, tratando de acercarse a la originalidad. Se cumplió con las directivas del Ministerio de Cultura para la intervención en bienes inmuebles, sin embargo, no se tomó en consideración las normas internacionales de éticas restaurativas, como la Carta de Venecia.

Debemos, por tanto, observar la preferencia de la conservación de la consistencia física. Pero no siempre se debe devolver al estado original a la obra, pues la historia de ésta forma parte de sus valores, y la apreciación del bien cambia con los años y los gustos, de forma que la restauración es también una cuestión estética y no solo técnica (Feliu, 2002, p. 107)

3. Ameritaban ser restaurados y, fueron contemplados ene le proyecto.

4. Como parte del segundo proceso de dorado, con presupuesto de la intervención de la Iglesia en su Conjunto. 


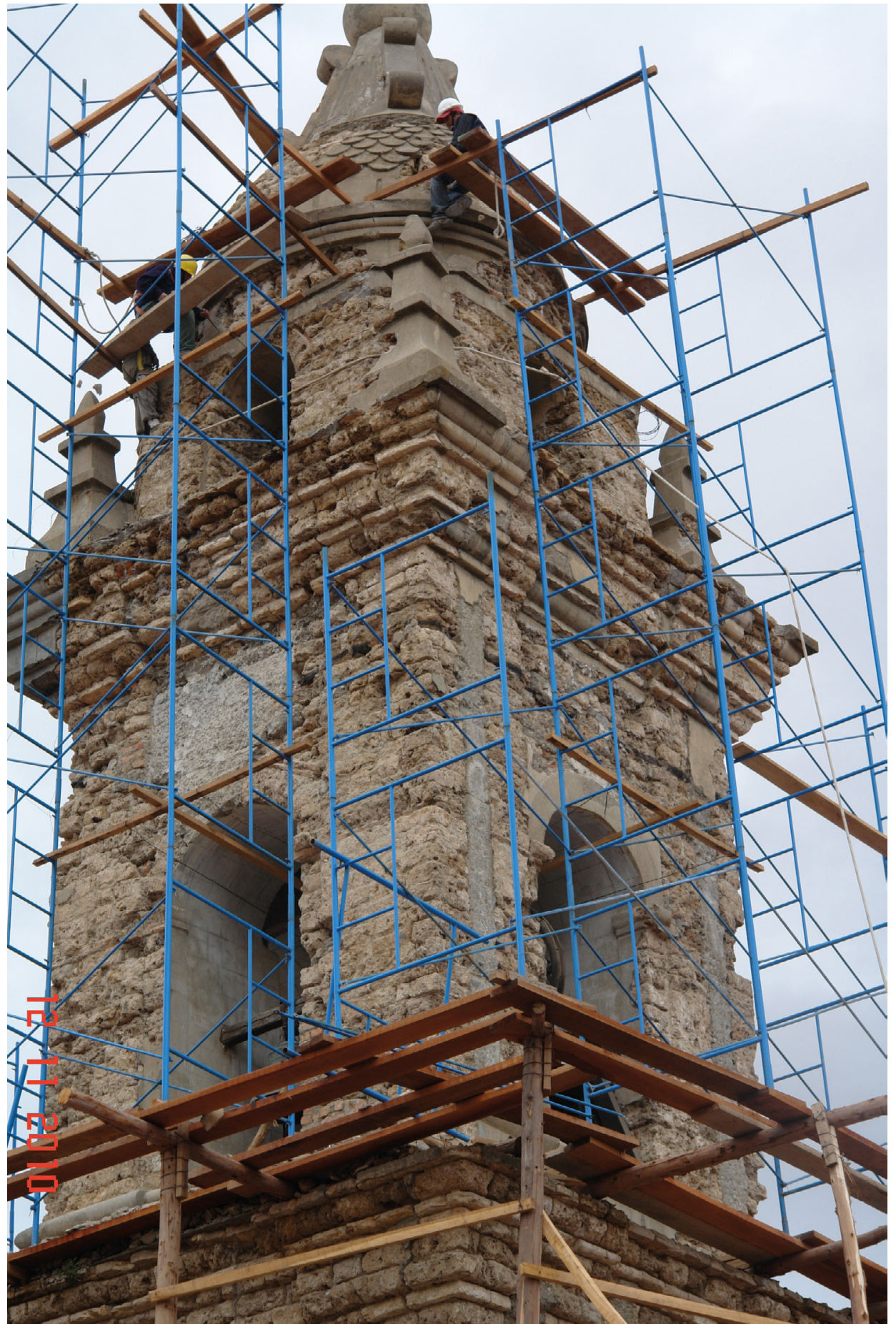

Figura 9. Torre de la Iglesia Matriz de Jauja, en proceso de intervención. Archivo Direccion Desconcentrada Cultura-Junín, 2010.

No se aplicó una metodología de la "restauración objetiva", tampoco un tratamiento de especificidad unidad e historicidad, como criterio básico de intervención moderna; simplemente se protegió el valor arquitectónico con fines turísticos, y no los valores de significado y testimonio, que propone las metodologías en referencia, pero sí predominó una propuesta de "restauración histórica", cuyos resultados despertaron una sensibilización y conciencia patrimonial. Tampoco se empleó la metodología "analógi-

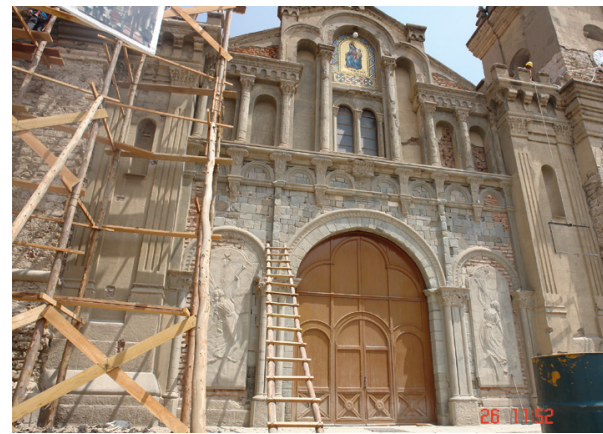

Figura 10. Iglesia Matriz de Jauja, evidenciando sobre el pórtico el enchape de piedra de principios del siglo XVIII. Archivo fotográfico de Percy Vílchez, 2010. 


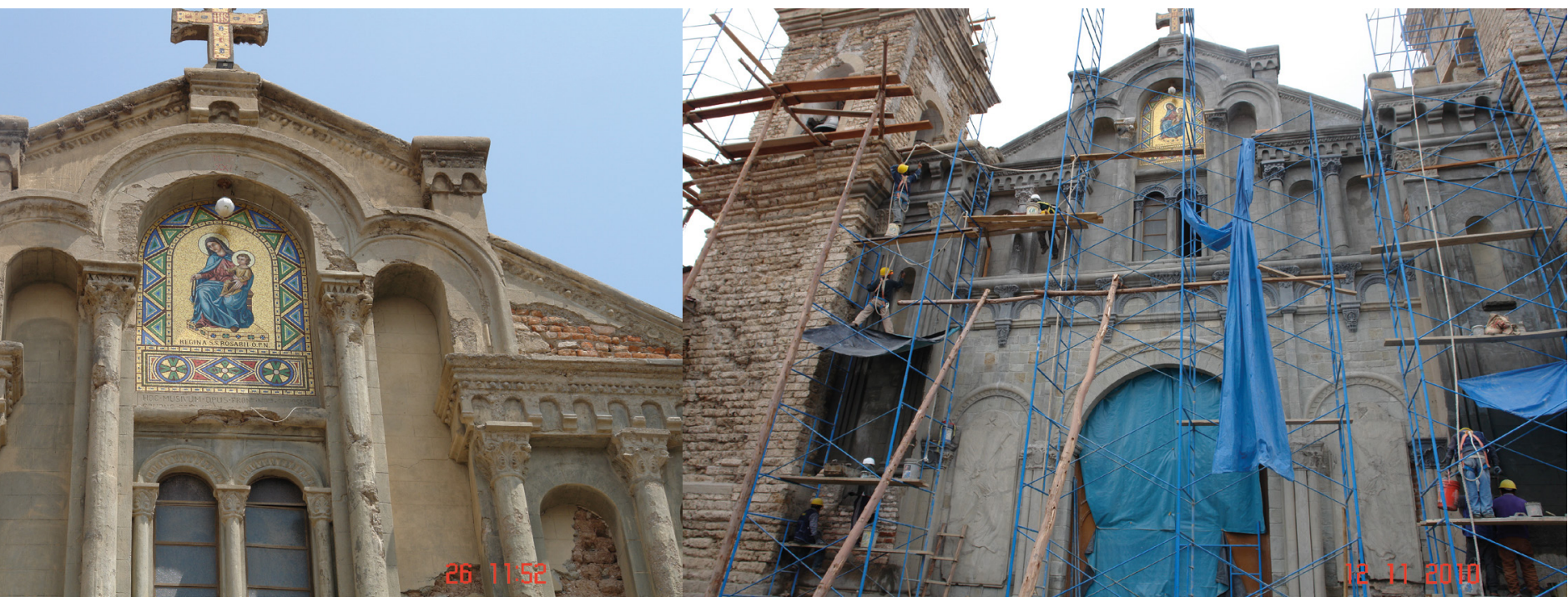

Figura 11. Detalle del segundo cuerpo del pórtico de la Iglesia Matriz de Jauja, en proceso de liberación del enlucido de cemento antiguo. Archivo fotográfico de Percy Vílchez, 2010.

Figura 12. Iglesia Matriz de Jauja, en proceso de intervención. Presenta la liberación del enlucido de cemento antiguo en la "torre campanario". Archivo fotográfico Direccion Desconcentrada Cultura-Junín, 2010. ca", salvo en el uso del material de la cal para el enlucido final, emulando la cal antigua del enlucido de la primera configuración de la iglesia en el siglo XVI.

Hicieron falta especialistas interdisciplinarios, como exhorta la Carta de Venecia (donde se manifiesta la salvaguarda y protección de los monumentos, mediante la conservación, restauración, con intervenciones multidisciplinarias y científicas, sin alteraciones, promoviendo su mantenimiento y respeto), pero en esta intervención solo se contó con profesionales y técnicos específicos.

En...una restauración arquitectónica esta debe reunir una serie de estudios previos entre los que se encuentra una investigación histórica del inmueble... una investigación iconográfico-histórica [sic], un análisis histórico-estructural del asentamiento urbanístico del área monumental que pongan de manifiesto las alteraciones sufridas desde su construcción primera y la consolidación experimentada en el tejido urbano que la envuelve, la individualización de los componentes arquitectónicos y artísticos, y el análisis de las relaciones y parámetros entre los distintos aspectos históricos, estructurales y artísticos del edificio para favorecer, con la restauración, su comprensión global. (Feliu, 2002, p. 124)

En cualquier caso la problemática de la restauración arquitectónica discurre... a través del desarrollo de todos los elementos fundacionales de cualquier disciplina: la aplicación de las metodologías más adecuadas tanto para el conocimiento del monumento en sus distintos valores como de sus patologías, el control de las técnicas tradicionales y el manejo oportuno de las nuevas tecnologías y la naturaleza del proyecto de restauración, tanto en la adopción de los criterios, como en la resolución del uso socio-cultural y funcional del edificio. (Rivera, 2003, p. 204) (ver Figuras 9 y 10)

Los procedimientos técnicos restaurativos, fueron de manera paralela para optimizar el trabajo de cada sector, desarrollados en tres etapas, iniciándose con el retiro del enlucido de cemento antiguo de la fachada -de forma compleja por la variedad y sinuosidad de los relieves ornamentales- y de las torres; así mismo el retiro de la cubierta dañada en diversos sectores del techado de la iglesia. En la segunda etapa se adecuó y consolidó nuevos materiales como revoque de cemento para las uniones de las piedras, y el cambio de tejados en la cubierta. La tercera etapa fue para el acabado de la fachada y las torres, con aplicación de revoque y nuevo enlucido de cal, también la consolidación del techado y la reparación de las partes dañadas. La intervención del 
altar retablo mayor, también fue en tres etapas, aplicación de pan de oro, bruñido del dorado y acabado final.

Los resultados no fueron de una intervención óptima bajo los principios científicos, éticos y metodológicos modernos en el campo restaurativo, porque desde la planificación del proyecto no se establecieron las metodologías correspondientes:

El proyecto de restauración debe contener todas las actuaciones que vayan a realizarse sobre el monumento... Las actuaciones que se propongan en el proyecto serán las dictadas por los resultados obtenidos en la etapa de estudios previos, cuya primera fase sería la de diagnóstico. En ella se realiza la investigación de los factores de alteración, agentes causantes de los mecanismos que han provocado transformaciones... La segunda parte se centraría en la propuesta de medidas correctoras, estudiando el efecto inhibidor que los posibles tratamientos puedan ejercer sobre la causa de deterioro. (Instituto Andaluz de Patrimonio Histórico, 2003, p. 10)

Faltó la investigación acuciosa, para que en el proceso de intervención se pudiera conocer el material y darle el tratamiento correspondiente, ya que una intervención óptima debe depender de la naturaleza del bien. No se tomó en consideración la dicotomía conceptual de conservación y restauración, simplemente se intervino; solo fue un tratamiento de conservación efímera, a modo de reparación o refacción, autorizado por la Directiva Técnica del Ministerio de Cultura, en tanto se respete y no se altere su estructura. Efectivamente, la estructura nunca fue intervenida, tampoco el volumen, a pesar de que el proyecto planteaba lo contrario, sobre todo en el interior de la iglesia. La finalidad era proteger las formas arquitectónicas para guardar relación con el ambiente urbano monumental y el centro histórico de la ciudad de Jauja, por tener una significación colectiva. (ver Figuras 11 y 12)

En cuanto a la calidad técnica, como trabajo de reparación parcial, no podría considerarse en los estándares de intervenciones óptimas, simplemente fue aceptable porque significó un logro dentro de la gestión cultural y dentro de nuestra realidad.

Respecto a los criterios de restauración y al fenómeno de la "autenticidad", con el retiro del enlucido de cemento, hubo la intención de recuperar la textura original de la edificación, pero en el acabado se emulaba un enlucido del siglo XVI, por falta de data histórica. Esta práctica genera desacertadas interpretaciones de "autenticidad". Qué podría ser original o auténtico en este monumento religioso, si su estructura muestra muchos cambios e intervenciones durante siglos, salvo que se precise a que época o periodo de intervención corresponde el supuesto "original", y es lo que no se hizo.

En la a sociedad había discrepancias sobre la intervención de acuerdo a la sensibilidad de cada cual y esto se hizo patente desde la gestación del proyecto hasta su culminación, donde las opiniones contrapuestas giraban en torno a la forma y el acabado. Algunos consideraban fundamental cambiar el tejado tradicional por cubierta de calamina moderna u otro material vistoso. Estos criterios posiblemente influyeron para que se mantuvieran las planchas de calamina antigua y, en el criterio para la intervención de la fachada, porque al no estar especificada la metodología de intervención los resultados no fueron aceptados de manera plena.

Hay diversidad de opiniones acerca de la calidad de la restauración de la Iglesia... la refacción del retablo principal ha sido trabajado [sic] por verdaderos profesionales, es decir artistas de primera calidad... En cuanto al frontispicio podemos decir que en la labor de extracción de la capa de cemento que la cubría... siempre se mutilaban pedazos de piedra volcánica adheridos a la argamasa o mortero; ese es el motivo de las críticas negativas que emiten algunas personas... con dicha fachada... (García, 2011, p. 2)

Para lograr la identidad sobre el patrimonio en referencia se planteó como estrategia realizar acciones de sensibilización e inclusión social: concursos escolares de pintura 
y dibujo sobre el imaginario de la iglesia matriz. Este proyecto también incluía la realización de eventos académicos para dar a conocer los valores históricos y artísticos de la Iglesia Matriz de Jauja. Como propuesta de acercamiento del bien edificado con la sociedad, el proyecto consideró -por iniciativa ciudadana ${ }^{5}$ - la divulgación mediática y la publicación de un libro sobre la intervención de la iglesia, que luego resultó un texto histórico sobre diversos componentes patrimoniales de la Provincia de Jauja.

\section{Propuesta restaurativa en torno a su valor simbólico, formal y de uso}

Toda iniciativa y proceso de intervención de un bien patrimonial para la conservación y restauración, tiene como finalidad hacer perdurable dicho bien, a fin de mantener sus valores de forma, significado y uso como elementos de identidad y pertenencia heredados de las sociedades anteriores. En este caso, la heredad de la Iglesia Matriz de Jauja, fue básicamente valorada por su aspecto formal y simbólico: las propuestas se concentraron en acciones de rescate del aspecto estético, soslayando el valor del conjunto arquitectónico en sí. Y, respecto al valor simbólico, el objetivo de la intervención hizo hincapié en su carácter espiritual y religioso sin enfatizar el significado histórico, social y cultural para su reconocimiento como patrimonio cultural, en su categoría de monumento histórico. Tal valoración, al destacar solamente el enlucido del edificio, generó controversias después de la ejecución del proyecto.

Por otro lado, no se consideró un nuevo valor de uso, solamente su tradicional carácter litúrgico, cuando en cualquier gestión para la intervención de un bien inmueble, es pertinente la incorporación de nuevos valores de uso, de acuerdo a las condiciones y demandas sociales que son fluctuantes en cada generación. Por ello, la propuesta del proyecto debió plantear la incorporación de un museo, un centro cultural o la incorporación de la iglesia como espacio del circuito turístico y artístico, y muchas otras propuestas de valores de uso que, lamentablemente, no se contemplaron en su momento.

\section{Interpretación sobre la gestión y el proyecto de intervención}

En la gestión de patrimonio cultural, la fase de elaboración y desarrollo del expediente técnico de un proyecto de restauración es de suma importancia ya que determina y garantiza la modalidad y éxito de una intervención. Es decir, la fase de ejecución se llevó a cabo de acuerdo a lo propuesto y analizado en el expediente técnico. Sin embargo, el proyecto que analizamos no puede ser considerado óptimo o ejemplar, debido a los escasos conocimientos técnicos y científicos y a la carencia de profesionales capacitados en el proceso de restauración, también por la falta de voluntad para recuperar todos los componentes patrimoniales. A pesar de estas deficiencias, primó la iniciativa, el compromiso y la relativa experiencia en ese tipo de acciones.

Por la ausencia de asesoramiento y exigencia de la entidad oficial competente, los proyectistas se conformaron con propuestas de baja factura y la intervención recayó en acciones genéricas, principalmente porque se contaba con un diagnóstico tradicional y escueto. No se utilizaron las tecnologías necesarias para el desarrollo integral del diagnóstico, tampoco se hicieron calas preliminares en la fachada; además se soslayó la condición de obras de arte y elementos patrimoniales, de las esculturas en relieve de la fachada, y falto aplicarse el escaneó tridimensional para un diagnostico científico a fin de observar la morfología de la iglesia.

La estructuración de la propuesta fue ligera porque solo cumplió con el diagnóstico básico, cuyos resultados de sugerencias se orientaron para una intervención de conservación y no de restauración, salvo para el caso de los componentes culturales mue-

\footnotetext{
5. Especialmente por los residentes locales, que en ese momento ocupaban cargos políticos y gerenciales de mucha influencia en la administración regional.
} 
bles, concernientes al altar retablo mayor y los retablos laterales ${ }^{6}$, para cumplir con la exigencia de la normatividad.

Por estas consideraciones, encontramos cuatro aspectos de infracción en el nivel de proposición del proyecto, para la intervención de la Iglesia Matriz de Jauja.

1. En cuanto al aspecto técnico, se manifiestan los siguientes puntos:

a) No se consideró la utilización de materiales constructivos iguales que los originales, como canterías, revoques, enlucidos y cubierta, cuando se proponía la restitución de estos elementos en determinados sectores. Por ningún motivo se debió permitir mantener las planchas de calamina en ciertos sectores de la cubierta, ya que estos fueron incorporados distorsionando su configuración de techado ${ }^{7}$, en lugar de indicar la restituir con tejado adecuado, por principio estético e histórico y por criterio de armonía paisajística.

a. No se debió proyectar la restitución de elementos decorativos dañados en la fachada frontal con material de fibra de vidrio, porque éticamente no es correcto, ya que el elemento decorativo en referencia fue incorporado con material de cemento a principios del siglo XX, por lo tanto, la solución apropiada era restituir con el mismo material, si por principio, se determinó conservar ese prototipo del pórtico de la fachada principal. ${ }^{8}$

b) Se debió intervenir el corredor lateral de la iglesia, que aún conservaba elementos arquitectónicos antiguos e importantes como arquerías, columnas y piso de ladrillo pastelero.

c) No se propuso recuperar el atrio frontal y lateral de la iglesia, que tiene elementos discordantes con la arquitectura, como los enrejados.

d) No se hizo mención a la intervención de los elementos patrimoniales en metal, como las campanas, enchapes y cerrajerías, mínimamente para una conservación preventiva. El proyecto solo se limitó a la limpieza de rejas de las ventanas interiores.

2. En el aspecto profesional la propuesta tampoco se realizó con criterios multidisciplinarios, porque la consultora encargada del proyecto solo requirió de arquitectos y de un historiador, cuando lo adecuado en esta fase, es convocar a diversos profesionales como arqueólogos, historiadores de arte, ingenieros ambientalistas, técnicos restauradores, comunicadores, entre otros, a fin de que la propuesta tome niveles científicos, por ejemplo el arqueólogo hubiera propuesto calas estratigráficas en determinados sectores de la iglesia, ya que históricamente se conoce la existencia del cementerio colonial en el atrio lateral derecho. El proyecto tampoco contempló la incorporación de estos profesionales en la fase de intervención, salvo la incorporación de técnicos restauradores, especialistas en retablos.

6. Durante el proceso de ejecución solo se efectuó la restauración del altar retablo mayor porque técnicamente requería la aplicación del "pan de oro" y restitución de elementos faltantes, como segunda fase de intervención, ya que la primera fase fue de conservación preventiva, gestionada por los miembros de la cofradía, específicamente para esa etapa. Pero coyunturalmente, fue favorable la iniciativa de recuperar la iglesia en el marco del proyecto de Jauja Monumental, en que los miembros de la cofradía y los consultores responsables del proyecto, no dudaron en anexarla para culminar con la segunda etapa, consistente en una labor estrictamente restaurativa.

7. En la segunda década del siglo XX llegaron a la región las planchas de calamina "Apolo" como nuevos productos vanguardistas en la construcción, cuyo uso tuvo mucha demanda tanto en las edificaciones nuevas como en las antiguas que no dudaron en sustituir los tradicionales tejados por estos nuevos artilugios.

8. Ya que significó un cambio radical en el proceso histórico de intervenciones en la Iglesia Matriz de Jauja y las múltiples configuraciones de propuestas estilísticas, siendo esta última de principios del siglo XX, la más trascendental.

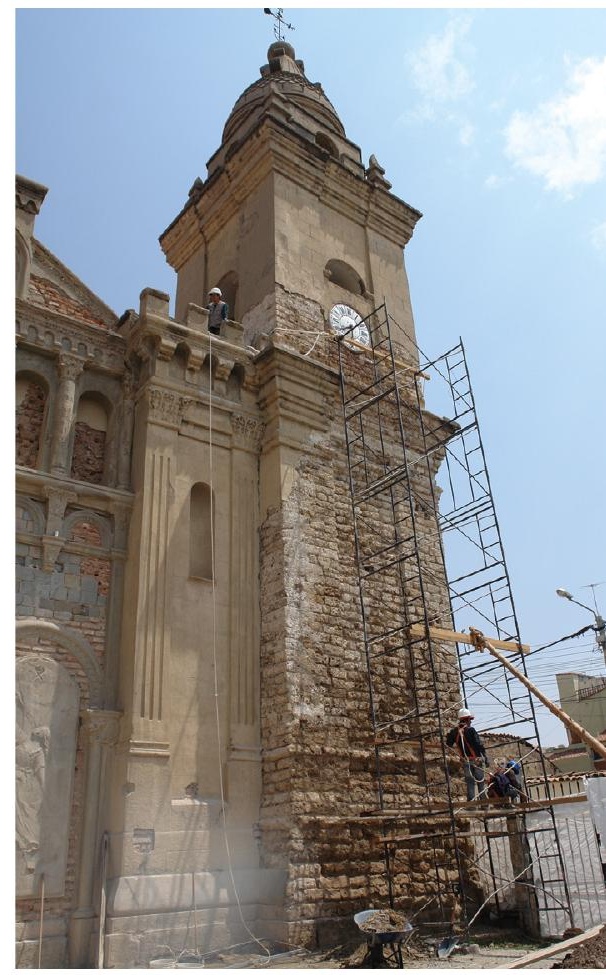

Figura 13. Torre lateral derecha de la Iglesia Matriz de Jauja, en proceso de intervención. Archivo fotográfico de Percy Vílchez, 2010

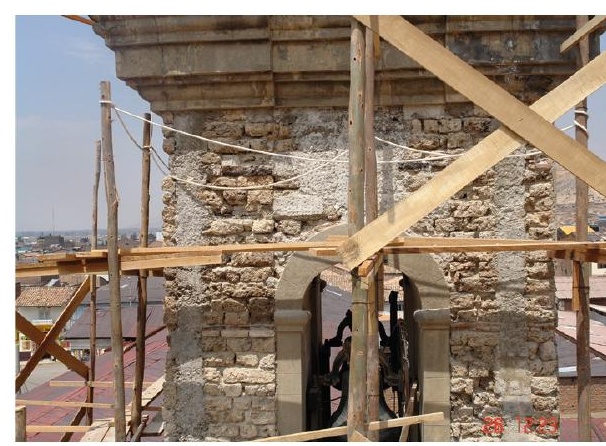

Figura 14. Detalle de la "torre campanario" de la Iglesia Matriz de Jauja, en proceso de intervención. Archivo fotográfico de Percy Vílchez, 2010. 
ción del proyecto solo se restauró un retablo por falta de presupuesto, perdiéndose la oportunidad para que todos los retablos sean intervenidos correctamente y en lugar de esa posibilidad fueron abandonados hasta la fecha, deteriorándose aún más.

4. Respecto a la ética de restauracíon no se empleó un método apropiado para este tipo de edificaciones, porque las propuestas se diseñaron, como si se tratara de un inmueble simple y moderno, por ello, en el expediente técnico orientaron su estudio analítico al aspecto de metrado, costos de las instalaciones eléctricas y a las intervenciones arquitectónicas señaladas.

De haber existido una evaluación más detallada sobre el estado de conservación de la iglesia, el proyecto podría haber planteado no solo la intervención para remediar el deterioro existente, sino también la implementación de otros componentes vinculados al patrimonio, como por ejemplo un Museo de Arte Sacro, en los ambientes de la iglesia y de la Casa Parroquial, ya que se trataba de la nueva puesta en valor de uso de una histórica y significativa edilicia (ver Figuras 13 y 14).

\section{Ejecución restaurativa en torno a la aprobación social}

El sentimiento de identificación por la magnitud del bien y el proceso de intervención, provoco expresiones sociales de reconocimiento a una identidad histórica, cuya significación se orientó al aspecto religioso, mediante el cual se canalizan las prácticas culturales y tradicionales de la Provincia de Jauja. Esta valoración colectiva en cuanto a la intervención arquitectónica, jerarquizó el resultado del trabajo, poniendo de manifiesto la relevancia en cuanto a su "reparación", ya que ello es significativo en la comunidad, porque garantiza su valor de uso, eminentemente religioso, quedando en segundo término la proyección estética. Sin embrago, con respecto a la intervención restaurativa del altar retablo mayor, la apreciación valorativa, se orientó al aspecto estructural y estético, en cuanto al primero, se reconoció su consolidación, recuperación y restitución del pan de oro, como forma de garantizar su estabilidad futura como elemento cultural mueble y arquitectónico principal del recinto religioso; y en cuanto al segundo, se admira hasta la actualidad su acabado reluciente y deslumbrante, que conecta con el significado espiritual que le da la sociedad.

Se enfatiza la utilidad religiosa del bien como fin supremo, por su valor de significado de devoción para la amplia mayoría, de forma incólume, pese a la intervención y posibilidades de otros usos en el ámbito cultural y turístico, ya que dicho monumento determina el modo de vida, la práctica tradicional y el imaginario cultural de sus ciudadanos, tanto de los que tienen arraigo permanente en el lugar, como de los residentes en otras ciudades, cuya admiración y uso, lo manifiestan en sus visitas esporádicas y en su difusión. (ver Figuras 15 y 16)

\section{Resultados de la recuperación del bien}

Los trabajos de intervención fueron concisos, sin alterar su valor de significado de uso, a pesar de que las razones para su restauración eran de carácter turístico, político y económico, de parte de los gestores, en tanto que, las consideraciones del colectivo social eran netamente de carácter religioso y la continuidad de uso.

En primer lugar, podemos hablar de un fin político, basado en que la recuperación de una obra pueda dar prestigio al que la realiza e incluso equipararlo con el del primer ejecutor de la misma. En segundo lugar, aunque no sea menos importante, podemos justificar muchas restauraciones por fines religiosos. Casi nunca exentos de un tinte político. Muchas obras restauradas lo han sido por criterios devocionales, como sigue ocurriendo hoy en día. No podemos olvidar, en tercer lugar, los fines económicos de las restauraciones, muchas veces involucrados en todas las intervenciones. Y por último... no descartamos el simple deleite estético (Feliu, 2002, p. 109)

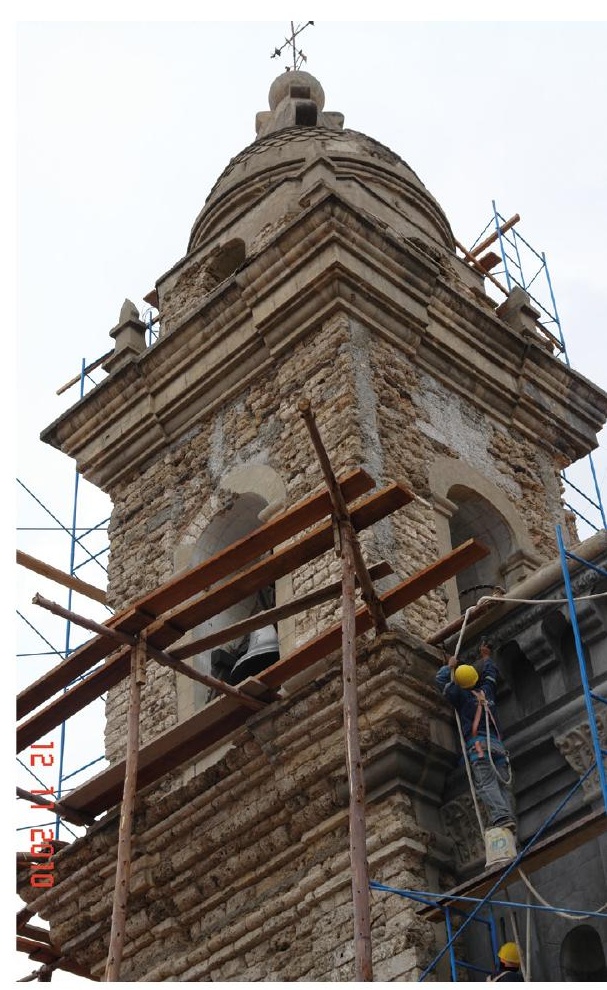

Figura 18. Torre campanario de la Iglesia Matriz de Jauja, en proceso de retiro del enlucido de cemento. Archivo fotográfico Direccion Desconcentrada Cultura-Junín, 2010. 

devenir Vol. 7, N¹4, JULIO - DICIEMBRE 2020, PP. 71-90 - EstudIOS I ISSN 2312-7562 | E-ISSN 2616-4949

UNIVERSIDAD NACIONAL DE INGEENIERÍA, LIMA

doi: https://doi.org/10.21754/devenir.v7i14.808

para el proceso de restauración. Sin embargo, hubo acercamiento metodológico en la "restauración histórica", por el sentido y orientación del trabajo al ámbito de la arquitectura del monumento religioso de Jauja, especialmente en cuanto al material constructivo.

También faltó consignar las principales técnicas modernas de restauración y en la intervención predominó la reparación o refacción de la fachada.

Además, no se tomó en cuenta las normas internacionales que recomiendan la intervención multidisciplinaria y su concepto de valor tan necesario, así como técnicas modernas de restauración para un trabajo óptimo.

Por último, el sentido de recuperación fue mínimo, salvo la restauración del altar retablo mayor. En consecuencia, el tratamiento del bien patrimonial tuvo carencias en la dimensión cultural. (ver Figura 20)

\section{Referencias}

Ballart, J. (2002). Patrimonio arqueológico. Valor y uso. Barcelona, España: Ariel S.A.

Capitel, A. (1992). Metamorfosis de monumentos y teorías de la restauración. Madrid, España: Alianza Editorial S.A.

Carbonara, G. (2005). Tendencias actuales de la Restauración en Italia. Logia, (6), 12-23.

Chipana, A. (2009). Proyecto: Puesta en Valor, Recuperación y Conservación de la Zona Monumental de la Ciudad de Jauja. Componente: Refacción Iglesia Matriz de Jauja. Huancayo, Perú: Mecanografiado.

Comisión del II Congreso Internacional de Arquitectos y de Técnicos de Monumentos Históricos. (1964). Carta de Venecia. Venecia, Italia: Consejo Internacional de Monumentos y de Sitios ICOMOS - UNESCO

Cuadros, H. (19 noviembre de 2012). Convento e Iglesia Matriz de la Orden franciscana. Primicia, p. 11

Feliu, J. (2002). Conservar el devenir: en torno al patrimonio cultural valenciano. Castello de la Plana, España: Universidad Jaumé I.

García, H. (2011). Para el recuerdo: Zona Monumental de Jauja. El Rajatabla Regional, (15), 2.

Hinostroza, N. y Cuadros, H. (2010). El patrimonio arquitectónico y artístico de Jauja. En Dirección Regional de Comercio Exterior y Turismo Junín. Gobierno Regional de Junín. (ed.) Jauja, Pedacito de Cielo, (pp. 69 - 89). Huancayo, Soluciones Gráficas SAC.

Huaroc, V. (2010). Presentación. En Dirección Regional de Comercio Exterior y Turismo Junín. Gobierno Regional de Junín. (ed.) Jauja, Pedacito de Cielo, (p. 7). Huancayo, Soluciones Gráficas SAC.

Instituto Andaluz del Patrimonio Histórico. (2003). Metodología de diagnóstico y evaluación de tratamientos para la conservación de los edificios históricos. Sevilla, España: Consejería de Cultura-IAPH.

Mattos, L. y Pujal, A. (Ed.). (2002). Curso de capacitación y transferencia de tecnología para la conservación de edificios de valor histórico monumental. Buenos Aires, Argentina: Instituto Italo-Latinoamericano.

Muñoz, S. (2003). Teoría contemporánea de la restauración. Madrid, España: Editorial Síntesis S.A.

Rivera, J. (2001). De varia restauratione: Teoría e historia de la restauración arquitectónica. Valladolid, España: R\&R Restauración y Rehabilitación.

Rivera, J. (2003). Nuevas tendencias en la identificación y conservación del patrimonio. Valladolid, España: Universidad de Valladolid.

Yañac, J. (2010). Metrado de obra de Iglesia Matriz para el proyecto: Puesta en Valor, Recuperación y Conservación de la Zona Monumental de la Ciudad de Jauja. Componente: Refacción Iglesia Matriz de Jauja. Huancayo, Perú: Mecanografiado. 